\title{
Kenyan dispute illuminates bioprospecting difficulties
}

Sensitivities surrounding the politically charged issue of bioprospecting were thrown into stark relief during September by reports that the Kenya Wildlife Service (KWS) planned to launch a multi-million dollar legal claim against Genencor and Procter \& Gamble, alleging that a microbial cellulase enzyme illegally obtained from a soda lake in the country was used as an ingredient in the latter company's Tide laundry detergent. Media reports of the controversy played out a familiar narrative: piratical multinational corporations stealing biological resources from an impoverished developing country. As Nature Biotechnology went to press, however, negotiations between Genencor and the KWS had opened, and an amicable resolution appeared to be in the offing.

Genencor, of Cambridge, Massachusetts, has never hidden the fact that it markets two industrial cellulases, IndiAge Neutra and Puradax, which were obtained from Kenyan extremophile isolates that can withstand harsh alkaline environments. But their combined sales are modest, amounting to less than $\$ 5$ million annually, according to Jack Huttner, Genencor's vice president of communications and public affairs. $\mathrm{He}$ categorically denies that Cincinnati, Ohiobased Procter \& Gamble uses either product.

Genencor obtained the isolates in 1995, when it purchased the industrial enzymes business of Gist-brocades, now part of DSM, of Heerlen, the Netherlands. They were taken from two Kenyan lakes, Bogoria and Nakuru, during a 1992 bioprospecting expedition led by William Grant of British Leicester University and hosted by Kenyatta University of Nairobi. Huttner says the expedition obtained the necessary permits from Kenya's National Council for Science and Technology, and Kenyatta University received training and laboratory equipment and supplies as part of the original agreement.

However, the KWS, which has jurisdiction over protected areas in the country, claims that additional permits were required because the territory involved was covered by its remit, says Peter Munyi, a Nairobi-based lawyer advising the agency on the case. Munyi declined to comment on what reparations the KWS is now seeking, because negotiations with Genencor are still at an early stage. Genencor's Huttner says the initial correspondence it received from the KWSafter media reports had surfaced in Kenya and in the UK-sought merely to establish the facts of the case.
Regardless of its eventual outcome, the dispute highlights the legal and ethical minefield that biotech companies must negotiate if they want to engage in this kind of research. The UN Convention on Biological Diversity (CBD), ratified by more than 175 countries since being adopted by the 1992 Earth Summit in Rio de Janeiro, is the principal international legal instrument that governs bioprospecting. Its provisions on "fair and equitable sharing of the benefits [e.g., royalties from resulting commercial products; knowledge transfer; support for training initiatives] arising out of the utilization of genetic resources" form the basis of agreements between research organizations and the countries in which they conduct work.

But the whole area is still dogged by controversy. According to Calestous Juma, former executive secretary of the CBD and current professor of the practice of international development at Harvard University, there are problems on both sides-industry needs to define and sign up to best practice, whereas developing countries need to develop coherent biotech policies based on their long-term interests and needs. "A lot of this is a failure not of legal systems, but a failure of finding ways in which developing countries can be genuine partners in biotechnology development," says Juma.

"No one has problems with sharing the benefits through the contractual agreements as long as there is transparency," says Lila Feisee, director of intellectual property at the Washington, DC-based Biotechnology Industry Organization, which is currently drawing up guidelines on bioprospecting for its members. Up to now, she says, there has been a lack of clarity and lack of uniformity in

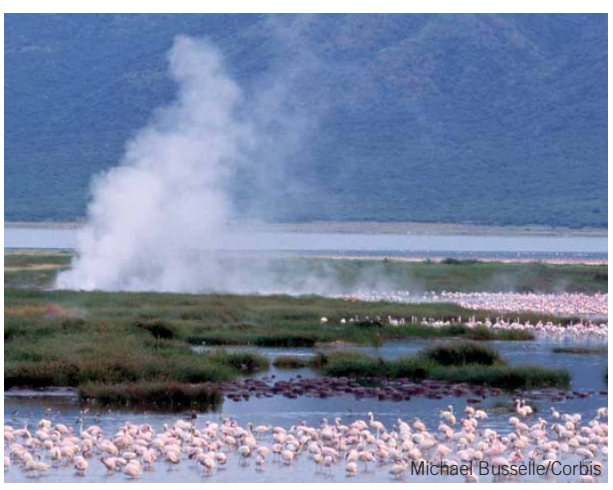

Pink flamingos gather near a hot spring along the shores of Lake Begoria, Kenya.

implementing the CBD that makes it difficult for companies to decide whether they want to do business in a particular country (see Box 1).

"Part of the problem is you have an unimaginable imbalance of experience and power" between developing countries with poorly resourced regulatory agencies and large multinational corporations, says Michael Gollin, chairman of Washington, DC-based Public Interest Intellectual Property Advisors, a non-profit organization that links developing countries with attorneys who are willing to work on a pro bono basis in intellectual property disputes. Many developing countries lack the scientific or legal capacity to enable equal participation in bioprospecting projects, he says.

Although Juma, who is Kenyan, says there are some positive signs that developing countries can use bioprospecting agreements to bolster their own scientific capacity, there are also outstanding cases that could lead to further disputes. "There are several Kenyan cases I am aware of that could come up," he warns.

Cormac Sheridan, Dublin

\section{Box 1 Sweden tries to shore up CBD responsibilities}

In early September, the Swedish Foreign Ministry and the National Board of Trade proposed linking the country's patent system to its obligations under the $\mathrm{CBD}$, by requiring patent applicants to make additional disclosures on the origin of biological materials in cases where they were obtained from developing countries. This would provide stakeholders from developing countries a degree of leverage in any disputes that would flow from bioprospecting agreements drawn up under the auspices of the convention. But SwedenBio, a Stockholmbased biotech industry lobby, has objected, saying that the patent system is not designed to facilitate the kind of benefit-sharing arrangements envisaged by the CBD.

"These provisions should be developed and set down in rules, but it should be done outside the patent system," says SwedenBio project leader Mats Berggren. "From the point of view of the patent system, the patent has to go to the person who made the inventive contribution," says Niklas Mattsson, of Malmo, Sweden-based IP consultants Awapatent, who contributed to a SwedenBio position paper on the issue. 